\title{
Sub-populations of coastal cod with different behaviour and life-history strategies
}

\author{
Anne Gro Vea Salvanes ${ }^{1,3, *}$, Jon Egil Skjæraasen ${ }^{1}$, Trygve Nilsen ${ }^{2}$ \\ ${ }^{1}$ Department of Fisheries and Marine Biology and ${ }^{2}$ Department of Mathematics, University of Bergen, PO Box 7800, \\ 5020 Bergen, Norway \\ ${ }^{3}$ Present address: University College London, Galton Laboratory, Wolfson House, 4 Stephenson Way, London NW1 2HE, UK
}

\begin{abstract}
This study provides evidence of countergradient variations in life-history traits among coastal cod Gadus morhua off the Norwegian coast, suggesting the existence of sub-populations. One-yr-old wild-caught individuals from $70^{\circ} \mathrm{N}$ were smaller, grew slower, weighed less, and had a lower condition factor (CF) than southern cod from $60^{\circ} \mathrm{N}$ during the sampling period from June to February. In contrast, both a higher growth potential and an increase in CF were found in northern cod when offspring of northern and southern cod from the same area and of the same age as the wild cod were housed together in a 'common-garden' experiment. The rapid growth in northern cod was achieved by higher success in food competition when given a restricted amount of food. Active feeding behaviour and larger energy allocation to storage tissues, as suggested by the higher increase in condition, represents adaptations to the high-latitude environment for northern cod and countergradient variation. These differences suggest the existence of genetically distinct sub-populations along the Norwegian coast. Development of sub-populations that differ in behaviour and life-history strategies are discussed in relation to mechanisms for local retention of early life stages and local adaptation of older stages. Sub-populations with different life histories may respond differently to fisheries, and attention to this could be beneficial for improving fisheries management.
\end{abstract}

KEY WORDS: Coastal cod · Countergradient variation $\cdot$ Behaviour $\cdot$ Fisheries management $\cdot$ Local adaptation $\cdot$ Sub-populations

Resale or republication not permitted without written consent of the publisher

\section{INTRODUCTION}

Populations distributed over a wide range of environments may form distinct sub-populations that vary in life-history traits (Law 2000). The dynamics of subpopulations largely depend on growth and mortality rates, age and size at maturation and fecundity. These life-history traits all influence fitness and should therefore adapt to local selection regimes (Sutherland 1996, Carrol \& Corneli 1999, Law 2000). Since individuals' size affects their survival, maturation and fecundity, maximising growth rate should be a major influence on life history (Arendt 1997).

However, evidence exists that most organisms are capable of growth rates far greater than what is found in nature (Calow 1982), suggesting trade-offs between growth and other life-history traits (Arendt 1997). For example, temperature is correlated with growth rate (Jobling 2002), and this may to varying degrees constrain the realised growth rate in different environments. Growth rates have also been found to a have a genetic component (e.g. Gjerde 1986, Elliott 1989, Law 2000), and should therefore respond to selection (e.g. Arendt 1997). Evolution of genetically differentiated sub-populations in species distributed over wide range of environments is therefore likely, as long as there are mechanisms ensuring local retention of early life stages (Asplin et al. 1999, Cowen et al. 2000).

Along a latitudinal gradient there will typically be changes in ambient temperature and seasonal variation in photoperiod, differences in encounter rates with prey, predators and competitors, and variations in the strength, temporal pattern and direction of ocean currents. In the Northern Hemisphere growth is generally 
more constrained by a shorter growth season and lower temperature at higher latitudes. To counteract the negative effect of the environment on growth, high-latitude populations may evolve local adaptations to maximise growth, i.e. countergradient selection (Levins 1969, Hutchings \& Morris 1985, Conover \& Present 1990, Conover \& Schultz 1995, Arendt 1997, Foster \& Endler 1999, Jobling 2002). In species within which countergradient selection on growth occurs, high-latitude populations show higher growth potential than their southern conspecifics when their normal environmental stress is absent. This has been documented in plants, insects and poikoliterms (Partridge et al. 1994, Conover \& Schultz 1995, Arendt 1997).

A likely hypothesis for countergradient selection in growth is that it occurs when limiting factors such as a short growth season exist (Arendt 1997). The length of the growth season depends on the integrated amount of daylight available for visual feeding during the entire growing season (Suthers \& Sundby 1996), food availability and ambient temperature (Jobling 2002). The rates at which individuals grow also influence their survival probability. Winter mortality is greater in small fish because smaller energy reserves cause a higher risk of starvation during periods of food shortage. Small fish will also be at greater risk of being preyed upon by predators. Mortality is therefore assumed to be greater at higher latitudes (Conover \& Present 1990), particularly if food competition is high. One way of surviving periods of food shortage is to allocate energy to reserves when food is plentiful. These reserves can then fuel metabolism in times of need. This strategy is affected by a trade-off between storage costs and needs (Bull et al. 1996). When encountering food, fish at high latitudes, which experience prolonged food shortage, should allocate more energy to storage tissues than fish less constrained by their environment (Bull et al. 1996).

The North Atlantic cod (Gadus morhua L.) consists of many populations and sub-populations with different life histories, which are distributed on the west and east coast of the North Atlantic (Mork et al. 1985, Brander 1994b, Bentzen et al. 1996, Svåsand et al. 1996, Fevolden \& Pogson 1997, Ruzzante et al. 1998, Jonsdottir et al. 2002). Populations in warm water grow faster and mature earlier than those in colder water (Hutchings et al. 1993, Brander 1994b). Previous studies have reported photoperiod affecting growth in cod larvae, with those in northern latitudes having a longer time for visual feeding during summer (Suthers \& Sundby 1996), and higher food-conversion efficiency in northern cod compared with southern cod off the coast of Canada (Purchase \& Brown 2000). Some of the units are heavily overfished and have collapsed; they have shown slow recovery even under a complete fish- ing moratoria (Hutchings 2000). Others are declining dramatically, including the coastal cod in Norwegian waters, which is distributed over a distance of more than $2000 \mathrm{~km}$ along the coast.

In Norwegian waters the sub-population concept has largely been ignored in fisheries management (Anon 2003). Some evidence of differentiation along the Norwegian coast has been found, however. Variation in noncoding DNA shows a north-south gradient in the frequency distribution of neutral isozymes among coastal cod (Mork \& Giaever 1999). There has, however, been no study on the geographic structure of genes influencing fitness and the possibility of countergradient variation and sub-populations for Norwegian coastal cod. The extent of local adaptation and the existence of sub-populations is likely to be underestimated by selectively neutral molecular genetic traits (Conover 2000), and 'common-garden' experiments examining traits related to fitness, such as growth, are needed to address this issue (e.g. Conover \& Schultz 1995, Foster \& Endler 1999).

Higher growth potential could be achieved by higher food consumption through a more active feeding behaviour and higher competitive ability. Higher foodconversion efficiency, or a combination of both effects, would also result in a higher growth potential in northern forms. This study is the first to employ 'commongarden' rearing, using cod reared from eggs from 'northern' $\left(70^{\circ} \mathrm{N}\right)$ and 'southern' $\left(60^{\circ} \mathrm{N}\right)$ Norway to test whether they differ in (1) feeding behaviour, growth and food-conversion efficiency and (2) energy allocation between skeletal growth and storage tissues. Consistent differences imply adaptation to different environments and hence sub-populations. Field data derived from Svåsand et al. (2000), from the area of origin of the parental fish, are included for comparison of growth between northern and southern coastal cod in the field.

\section{MATERIALS AND METHODS}

Study species. Cod develop through pelagic egg and larval stages with vertical distributions in the intermediate dynamic water masses ( 0 to $50 \mathrm{~m}$ depth), potentially causing a wide dispersal of early life stages by non-local, wind-driven transport, which allows advection between fjords and coastal areas (Asplin et al. 1999). For cod in Norwegian waters the classic view is that there are only 2 major populations: the Northeast Arctic and the coastal cod populations, which differ in growth performance (Svåsand et al. 1996). The Northeast Arctic population has its nursery area in the Barents Sea and undertakes yearly spawning migrations from the Barents Sea to the north Norwegian coast from 7 to 8 yr of age (Bergstad et al. 1987, Nordeide \& Pettersen 1998). Coastal cod have a less migratory life 
style, remaining more or less in the same area from settlement at 4 to $5 \mathrm{mo}$ of age and onwards; they will also reproduce locally in fjords and coastal areas from an age of 3 to 5 yr (Jakobsen 1987, Salvanes \& Ulltang 1992, Nordeide \& Pettersen 1998).

Environmental gradients. Water temperature decreases as one moves in a northerly direction along the Norwegian coast. The major current is the Norwegian coastal current, which flows northwards with a speed between 30 and $50 \mathrm{~cm} \mathrm{~s}^{-1}$ down to $500 \mathrm{~m}$ depth (Blindheim 2004). The fjords of southern Norway have relatively high temperatures $\left(12\right.$ to $\left.16^{\circ} \mathrm{C}\right)$ during summer and autumn, but substantially lower temperatures during winter and spring (Svåsand et al. 2000). The fjords and coastal areas of northern Norway have a sub-arctic climate, with a temperature of 5 to $7^{\circ} \mathrm{C}$ all year round (Svåsand et al. 2000). Summer day length increases and winter day length decreases with latitude, causing latitudinal differences in opportunities for visual feeding (Suthers \& Sundby 1996) and seasonal differences in prey-encounter rates. The average cod biomass in northern fjords $\left(3.5 \mathrm{t} \mathrm{km}^{-2}\right)$ is about 4 times that of southern fjords $\left(0.8 \mathrm{t} \mathrm{km}^{-2}\right)$, due to higher recruitment and density of juveniles, the presence of few competing species and relatively low fishing mortality (Svåsand et al. 2000). This implies different selection regimes between high and low latitudes.

Fish. The northern brood stock consisted of wildcaught individuals from $70^{\circ} \mathrm{N}$ kept in an environmental regime characteristic of northern cod during maturation and spawning (natural photoperiod, 3.5 to $4.5^{\circ} \mathrm{C}$ ). The southern brood stock were comprised of first-generation cod from $60^{\circ} \mathrm{N}$ reared in hatcheries. These fish were kept in an environmental regime typical of southwestern Norway during maturation and spawning (natural photoperiod, 6 to $7^{\circ} \mathrm{C}$ ). The brood stocks spawned voluntarily in large tanks. The southern group consisted of 15 females and 10 males, and the northern group of 45 individuals with approximately $50 \%$ females. Eggs were collected over a $24 \mathrm{~h}$ period. Female cod release batches approximately every other day, implying that approximately 7 to 8 and 12 to 13 females mothered larvae for the southern and northern fish, respectively. For the southern population this is likely a minimum number, since eggs were collected on days with a particularly high egg density. Fertilized eggs from the southern strain were spawned at Austevoll Aquaculture Station (near Bergen), but hatched in egg incubators at the University of Bergen (UoB) in April 2000, whereas fertilized eggs from the northern strain were spawned at Troms Marin Yngel (near Tromsø) before being transported to $\mathrm{UoB}$ and gradually acclimated to 5 to $6^{\circ} \mathrm{C}$. The eggs from both strains were then housed at a temperature of 5 to $6^{\circ} \mathrm{C}$ until $2 \mathrm{~d}$ before hatching; the temperature was then gradually increased to $10^{\circ} \mathrm{C}$, which was reached $2 \mathrm{~d}$ after hatching. The day for $50 \%$ hatching was identical for the 2 groups.

Larvae were fed natural zooplankton until late June, and thereafter commercial fish feed (Supra Marine; Felleskjøpet, Norway). The cod were housed under typical natural light and temperature conditions representative of Bergen $\left(60^{\circ} \mathrm{N}\right)$, and from June onwards they were provided with a water renewal rate of $5 \mathrm{l} \mathrm{h}^{-1}$. Northern and southern cod were housed in separate aquaria prior to the experiments. Both groups of fish were treated identically prior to the experiments. The larvae were not sorted into size groups. A few cannibals were removed from both the northern and southern fish, but only over a $1 \mathrm{wk}$ period approximately $10 \mathrm{wk}$ after hatching to avoid further cannibalism. The temperature varied seasonally between 8 and $10^{\circ} \mathrm{C}$. In May 2001, samples of 30 individuals were selected at random from each population and transferred to 2 separate 70001 aquaria. At this time the diet was changed to natural cod food: herring (Clupea harengus) pieces, which were provided in small amounts during a $3 \mathrm{wk}$ acclimation period and from late May given as 2 larger meals per week for 6 wk. During this period, 2 individuals from the southern population escaped from the aquaria, and another individual was removed from the experiment.

The experiment. From the start of and throughout the experiment, northern and southern cod shared two $7000 \mathrm{l}$ aquaria (i.e. 'common-garden' rearing), in which there was a continuous water renewal rate of $2000 \mathrm{l} \mathrm{h}^{-1}$ in each, and a natural light cycle for Bergen.

The experiment started on 11 July. After anaesthetisation (Metakain), every individual was measured (total length, $\mathrm{cm}$ ), weighed (total weight, $\mathrm{g}$ ) and individually tagged. Feeding trials were conducted twice a week. The experimental groups were given similar-sized pieces of herring $(4.4 \mathrm{~g} ; \mathrm{SE}=0.16)$. Food items were provided sequentially in order to allow competition for each piece. Feeding terminated when food equivalent to $5 \%$ of the total biomass in each aquarium had been eaten or 4 items of food in a row had been rejected. Which individual took which food item was recorded.

Every other month the cod were anaesthetised, weighed and measured. After each measurement the food ration per aquarium was adjusted to $5 \%$ of the current biomass. The experiment was terminated on January 24. Four measurements were taken for individual fish (measuring dates were 11 July, 11 September, 13 November and 24 January). Hereafter, Period 1 refers to July-September, Period 2 to September-November, and Period 3 to November-January.

Field data. Data for wild cod of the same age (Svåsand et al. 2000) from the same areas as the origin of the brood stock were used to compare weight, length and condition factor for northern and southern coastal cod in their natural habitats. 
Data analysis. Wild cod: Foulton's condition factor, $\mathrm{CF}=\left(W / L^{3}\right) \times 100$, was calculated from weight $(W)$ and length $(L)$. CF was calculated to serve as an index of energy allocation. Growth in length, weight and CF were modelled by linear regression comparing population differences in slope and intercept. The equation used was

$$
y_{i l}=\mu_{0}+\beta_{01}+\left(\mu_{1}+\beta_{11}\right) t_{i l}+e_{i l}
$$

where $y_{i l}$ denotes the measurement of the $i$ th fish from the 1 th population. Subscript 1 refers to a slope and 0 to a constant (i.e. intercept), $\mu_{0}$ and $\mu_{1}$ are the overall intercept and slope values, while $\beta_{01}$ and $\beta_{11}$ are the population specific effects and $e_{i l}$ is the unexplained error. The dates were coded as $t=0$ for 1 July, $t=4.5$ for 15 November and $t=7$ for 1 February. The NLME library of the Splus software was used in this and the following tests (Pinoheiro \& Bates 2000). A contrast treatment using the northern population as the reference value was used for all tests. $\beta_{02}$ (SN-diff) and $\beta_{12}$ (time:SN-diff) thus show the differences between the southern and northern population at the start of the experimental period (intercept, $\beta_{02}$ ) and differences in growth rate during the experimental period (slope, $\beta_{12}$ ) for all tests (see Tables 1-3). A positive value implies larger values for the southern population.

Reared cod: CF was calculated for each individual measurement. Growth curves were modelled for individual fish for $W, L$ and $C F$. This was done by regressing the quantity in question using time and some of the other explanatory quantities, with an individual slope for each fish varying randomly around a mean slope. The model that fit the data best was

$$
y_{i j k l}=\mu_{0}+\alpha_{0 k}+\beta_{0 l}+b_{0 i}+\left(\mu_{1}+\alpha_{1 k}+\beta_{1 l}+b_{1 i}\right) t_{j}+e_{i j k l}
$$

The subscripts $k$ and $i$ denote aquaria and fish, respectively. The time $t_{j}$ was coded as $0,1,2,3$. A Greek letter denotes a fixed effect and a Latin letter denotes a random effect. Other variables are identical to those in Eq. (1).

During the last period some of the fish did not compete for food, possible indicating maturation (Fordham \& Trippel 1999), and there was food left in the aquaria after the feeding trials. All data were therefore analyzed both including and excluding the last measurement.

Differences in the total food intake of the 2 populations for the periods between each of the measurement points were tested using a mixed-effect model with population-specific components in the intercept and slope. The population component in the slope was not significantly different from zero including $(p=0.18)$ or excluding the last period ( $\mathrm{p}=0.12$ ). The population- specific term in the slope could therefore be omitted and the equation becomes

$$
y_{i j k l}=\mu_{0}+\alpha_{0 k}+\beta_{01}+b_{i}+\mu_{1} t_{j}+e_{i j}
$$

The symbols have the same meaning as above. The same model was used on the data after food intake had been standardized to weight at the start of each time period in order to correct for size. Again, the population component in slope was not significant (including last period, $\mathrm{p}=0.19$; excluding last period, $\mathrm{p}=0.60$ ).

Differences in gross food conversion efficiency (GFCE) were tested by a separate analysis of co-variance (ANCOVA) test for each time period. The test was done on the relationship between food eaten relative to initial size versus weight gain relative to initial size using populations and aquaria as fixed effects. Homogeneity of slopes was tested for all measurement dates for both aquaria and populations.

$$
y_{i k l}=\mu_{0}+\alpha_{0 k}+\beta_{01}+\mu_{1} x_{i k l}
$$

where $x$ is food eaten relative to initial weight.

\section{RESULTS}

\section{Wild cod}

Southern cod were heavier, longer and had a higher $\mathrm{CF}$ when they were the same age as experimental reared cod at the start of Period 1 (Fig. 1, Table 1: $\beta_{02}$ ). The southern cod had higher weight increase, but significantly lower increase in CF than northern cod (Fig. 1, Table 1: $\beta_{12}$ ). There was no difference in length increase (Fig. 1, Table 1: $\beta_{12}$ ). 

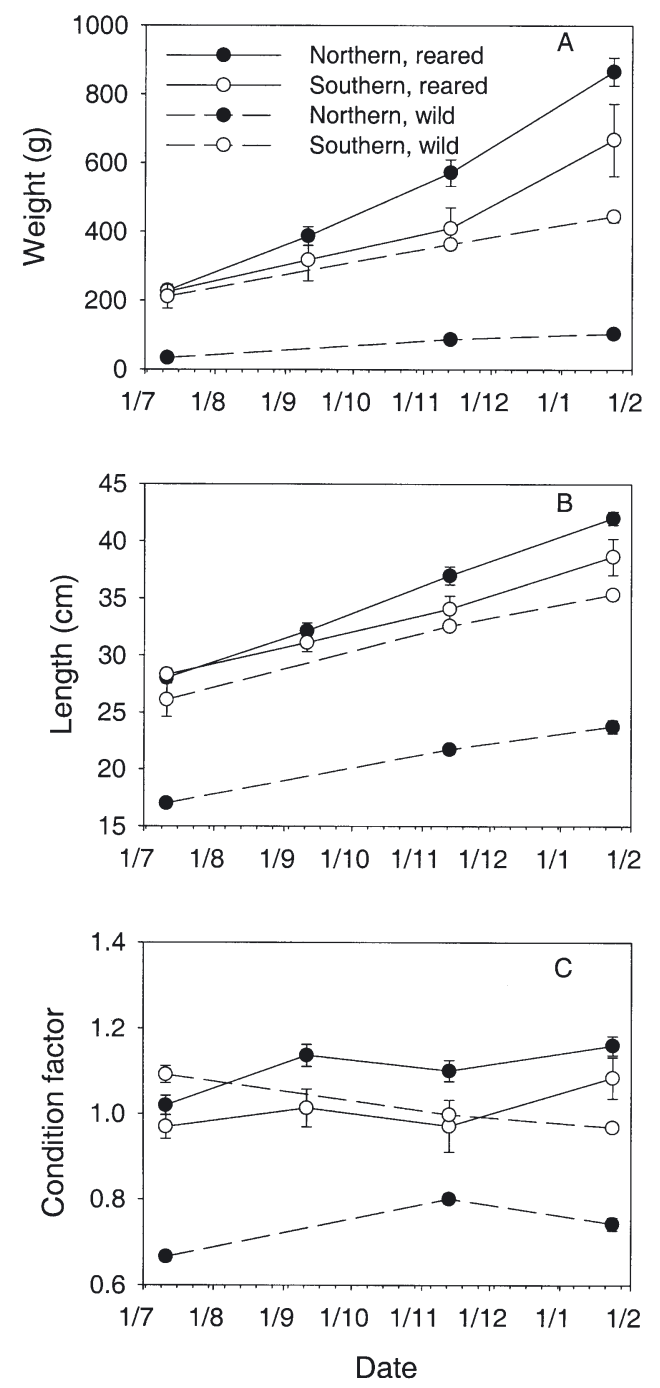

Fig. 1. Gadus morhua. Growth in (A) mean weight, (B) length and $(\mathrm{C})$ condition factor $(\mathrm{CF})$ in reared and wild cod. Date: date of measurement for the reared fish. Measurements for the wild cod are taken from the same month using fish of the same age (field data from Svåsand et al. 2000). Mean values of each measurement for the reared cod include all individu-

als alive at that point in time. Error bars: standard error

\section{Reared cod}

Contrasting results were obtained for reared cod from the 'common-garden' rearing experiment. There were no differences between aquaria in any of the variables measured (Fig. 1, Table 2). The interaction of aquaria:SN-diff was never significant ( $p>0.5)$, and it was therefore excluded from the model.

The coefficient $\beta_{02}$ (SN-diff intercept) was not significant for weight, length or CF (Table 2). Hence, the 2 populations were equal at the start of the experiment. The coefficients $\alpha_{02}$ (aquaria intercept) and $\alpha_{12}$ (slope of aquaria) were never significant (Table 2), i.e. the start and changes in the measured variables did not differ between aquaria. No aquarium effects were therefore detected in the study.

The most interesting coefficient, $\beta_{12}$ (time:SN-diff), which measures differences in increase in weight, length and $\mathrm{CF}$ for the southern population relative to the northern population, was highly significant for all variables including and excluding the last measurement (Fig. 1, Table 2). The negative value implies a smaller increase in southern fish (Table 2).

\section{Food intake}

Total food intake did not differ between aquaria (Table 3). As expected, the lower growth rate of southern cod was caused by significantly lower food intake due to lower success in feeding competition (consistent when including and excluding the last measurement; Fig. 2, Table 3). Normalised food intake gave the same results (Table 3 ).

\section{Gross food conversion efficiency}

We found no difference in GFCE between populations or aquaria (Fig. 2). The p-values for population comparisons were $p>0.53, p>0.24$ and $p>0.29$ for Periods 1,2 and 3 , respectively. For aquaria they were $\mathrm{p}>0.80, \mathrm{p}>$ 0.81 and $\mathrm{p}>0.12$, respectively, for Periods 1,2 and 3 .

\section{DISCUSSION}

The common-garden study presented here provides evidence of countergradient variations in life-history traits and suggests the existence of sub-populations of coastal cod in Norwegian waters. Wild individuals from $70^{\circ} \mathrm{N}$ were shorter, weighed less and had a lower $\mathrm{CF}$ at $1 \mathrm{yr}$ of age than southern cod caught at $60^{\circ} \mathrm{N}$ off western Norway (Fig. 1, and see Svåsand et al. 2000). From June to February the increase in weight of northern cod was also significantly lower, but they had a larger increase in CF than southern cod (Fig. 1). The latter implies a relatively higher allocation of energy to storage tissues (Fig. 1). In contrast, similar-age offspring of northern cod had a higher growth rate in length, weight and CF than southern cod when housed in a common-garden environment typical of the southern cod. No difference was found in GFCE (Fig. 2).

Two potential causes of bias concerning the parental fish need consideration: the number of generations in captivity, and the number of fish siring offspring for the reared southern and northern cod. The northern, 
Table 2. Gadus morhua. Effects on weight, length, and condition factor (CF) of population, aquaria and time for experimental coastal cod, estimated from random-effects modelling

\begin{tabular}{|c|c|c|c|c|c|c|c|c|c|c|}
\hline & \multicolumn{5}{|c|}{ Including last measurement } & \multicolumn{5}{|c|}{ Last measurement removed } \\
\hline & Value & $\mathrm{SE}$ & $\mathrm{df}$ & $t$ & $\mathrm{p}$ & Value & $\mathrm{SE}$ & $\mathrm{df}$ & $t$ & $\mathrm{p}$ \\
\hline \multicolumn{11}{|l|}{ Weight } \\
\hline Intercept, $\mu_{0}$ & 144.2 & 63.3 & 139 & 2.28 & $<0.05$ & 198.7 & 54.7 & 96 & 3.63 & $<0.001$ \\
\hline Aquaria, $\alpha_{02}$ & 18.2 & 17.8 & 51 & 1.02 & 0.31 & 8.0 & 15.4 & 51 & 0.52 & 0.604 \\
\hline SN-diff, $\beta_{02}$ & 10.4 & 18.0 & 51 & 0.58 & 0.56 & 0.3 & 15.5 & 51 & 0.02 & 0.98 \\
\hline Time, $\mu_{1}$ & 235.9 & 67.3 & 139 & 3.51 & $<0.001$ & 157.4 & 55.6 & 96 & 2.83 & $<0.01$ \\
\hline Time:Aquaria, $\alpha_{12}$ & -11.8 & 19.0 & 139 & -0.63 & 0.54 & 2.14 & 15.7 & 96 & 0.14 & 0.89 \\
\hline Time:SN-diff, $\beta_{12}$ & -71.3 & 19.3 & 139 & -3.69 & $<0.001$ & -57.7 & 15.8 & 96 & -3.65 & $<0.001$ \\
\hline Random effects & $\mathrm{SE}$ & Corr & & & & $\mathrm{SE}$ & Corr & & & \\
\hline Intercept, $b_{0 i}$ & 32.77 & & & & & 51.6 & & & & \\
\hline Time, $b_{1 i}$ & 59.12 & 0.805 & & & & 53.8 & 0.644 & & & \\
\hline Residual, $e_{i j k l}$ & 66.0 & & & & & 24.0 & & & & \\
\hline \multicolumn{11}{|l|}{ Length } \\
\hline Intercept, $\mu_{0}$ & 25.9 & 1.8 & 139 & 14.3 & $<0.001$ & 26.7 & 1.72 & 96 & 15.5 & $<0.001$ \\
\hline Aquaria, $\alpha_{02}$ & 0.62 & 0.51 & 51 & 1.21 & 0.23 & 0.38 & 0.49 & 51 & 0.78 & 0.44 \\
\hline SN-diff, $\beta_{02}$ & 0.26 & 0.51 & 51 & 0.50 & 0.62 & 0.26 & 0.49 & 51 & 0.54 & 0.59 \\
\hline Time, $\mu_{1}$ & 5.39 & 0.97 & 139 & 5.56 & $<0.001$ & 4.25 & 1.17 & 96 & 3.64 & $<0.001$ \\
\hline Time:Aquaria, $\alpha_{12}$ & -0.32 & 0.27 & 139 & -1.16 & 0.25 & 0.020 & 0.33 & 96 & 0.06 & 0.95 \\
\hline Time:SN-diff, $\beta_{12}$ & -0.93 & 0.28 & 139 & -3.33 & $<0.01$ & -0.94 & 0.33 & 96 & -2.83 & $<0.01$ \\
\hline Random effects & $\mathrm{SE}$ & Corr & & & & SE & Corr & & & \\
\hline Intercept, $b_{0 i}$ & 1.68 & & & & & 1.66 & & & & \\
\hline Time, $b_{1 i}$ & 0.85 & 0.349 & & & & 1.084 & 0.326 & & & \\
\hline Residual, $e_{i j k l}$ & 0.93 & & & & & 0.65 & & & & \\
\hline \multicolumn{11}{|l|}{ Condition factor } \\
\hline Intercept, $\mu_{0}$ & 1.03 & 0.11 & 139 & 9.34 & $<0.001$ & 1.04 & 0.108 & 96 & 9.6 & $<0.001$ \\
\hline Aquaria, $\alpha_{02}$ & $<0.01$ & 0.03 & 51 & 0.085 & 0.93 & 0.001 & 0.030 & 51 & 0.025 & 0.98 \\
\hline SN-diff, $\beta_{02}$ & -0.05 & 0.03 & 51 & -1.65 & 0.10 & -0.05 & 0.031 & 51 & -1.52 & 0.13 \\
\hline Time, $\mu_{1}$ & 0.034 & 0.041 & 139 & 0.825 & 0.41 & 0.025 & 0.050 & 96 & 0.49 & 0.62 \\
\hline Time:Aquaria, $\alpha_{12}$ & $<0.01$ & 0.012 & 139 & 0.127 & 0.90 & 0.004 & 0.014 & 96 & 0.31 & 0.76 \\
\hline Time:SN-diff, $\beta_{12}$ & -0.026 & 0.012 & 139 & -2.18 & $<0.05$ & -0.04 & 0.014 & 96 & -2.39 & $<0.05$ \\
\hline Random effects & SE & Corr & & & & $\mathrm{SE}$ & Corr & & & \\
\hline Intercept, $b_{0 i}$ & 0.094 & & & & & 0.091 & & & & \\
\hline Time, $b_{1 i}$ & 0.022 & -0.15 & & & & 0.008 & 0.86 & & & \\
\hline Residual, $e_{i j k l}$ & 0.074 & & & & & 0.069 & & & & \\
\hline
\end{tabular}

Table 3. Gadus morhua. Results of linear mixed-effect model on total food intake and food intake normalised to weight at the start of each period for experimental coastal cod

\begin{tabular}{|c|c|c|c|c|c|c|c|c|c|c|}
\hline & \multicolumn{5}{|c|}{ Including last period } & \multicolumn{5}{|c|}{ Last period removed } \\
\hline & Value & SE & df & $t$ & $\mathrm{p}$ & Value & SE & $\mathrm{df}$ & $t$ & $\mathrm{p}$ \\
\hline \multicolumn{11}{|l|}{ Total intake } \\
\hline Intercept, $\mu_{0}$ & 311.7 & 58.9 & 87 & 5.29 & $<0.001$ & 254.2 & 49.1 & 44 & 5.18 & $<0.001$ \\
\hline Aquaria, $\alpha_{02}$ & 5.61 & 27.3 & 44 & 0.2 & 0.84 & 26.6 & 23.1 & 44 & 1.15 & 0.26 \\
\hline SN-diff, $\beta_{02}$ & -81.2 & 27.7 & 87 & -2.93 & $<0.01$ & -57.6 & 22.6 & 44 & -2.55 & $<0.05$ \\
\hline Time, $\beta_{1}$ & 110.8 & 12.8 & 87 & 8.63 & $<0.001$ & 93.4 & 13.2 & 44 & 7.1 & $<0.001$ \\
\hline Random effects & $\mathrm{SE}$ & & & & & $\mathrm{SE}$ & & & & \\
\hline Intercept, $b_{0 i}$ & $\overline{59.1}$ & & & & & $\frac{N L}{63.0}$ & & & & \\
\hline Residual, $e_{i j k l}$ & 118.9 & & & & & 61.6 & & & & \\
\hline \multicolumn{11}{|c|}{ Normalised intake } \\
\hline Intercept, $\mu_{0}$ & 1.11 & 0.13 & 87 & 8.76 & $<0.001$ & 1.11 & 0.15 & 44 & 7.65 & $<0.001$ \\
\hline Aquaria, $\alpha_{02}$ & -0.013 & 0.06 & 44 & -0.22 & 0.82 & 0.048 & 0.07 & 44 & 0.73 & 0.47 \\
\hline SN-diff, $\beta_{02}$ & -0.124 & 0.06 & 87 & -2.08 & $<0.05$ & -0.18 & 0.07 & 44 & -2.60 & $<0.05$ \\
\hline Time, $\beta_{1}$ & 110.8 & 12.8 & 87 & 8.63 & $<0.001$ & 93.4 & 13.2 & 44 & 7.1 & $<0.001$ \\
\hline Random effects & $\mathrm{SE}$ & & & & & $\mathrm{SE}$ & & & & \\
\hline Intercept, $b_{0 i}$ & $\overline{59.1}$ & & & & & 63.0 & & & & \\
\hline Residual, $e_{i j k l}$ & 118.9 & & & & & 61.6 & & & & \\
\hline
\end{tabular}



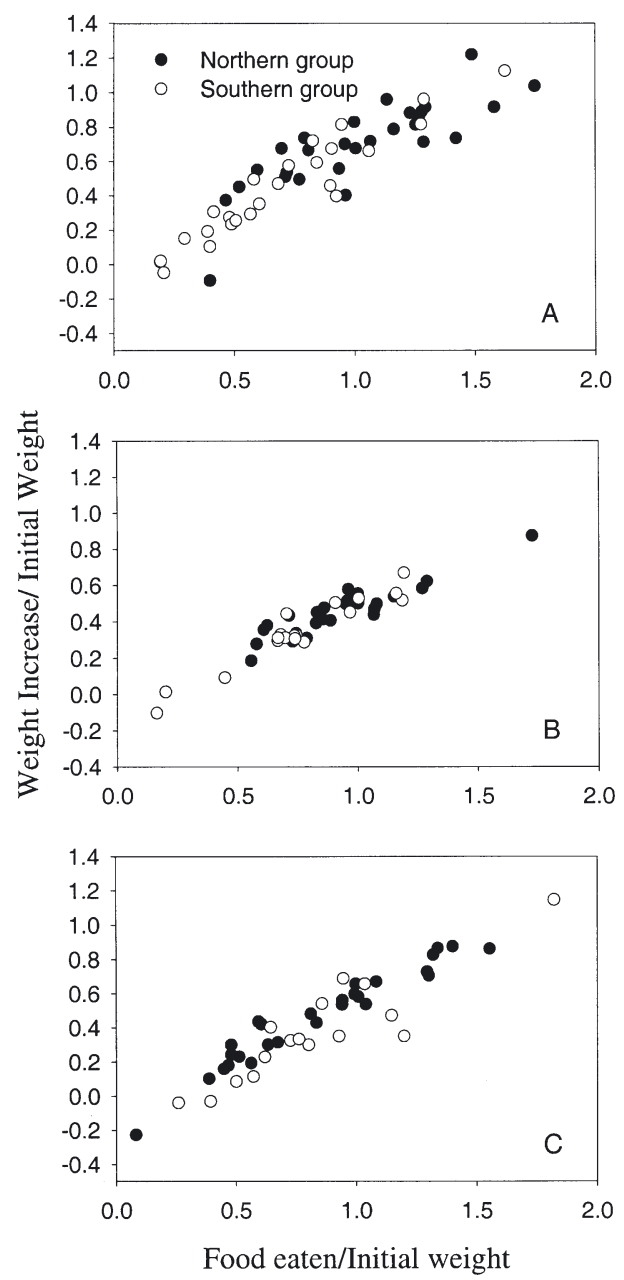

Fig. 2. Gadus morhua. Food conversion efficiency: relationship between food eaten/initial weight and growth/initial weight in northern and southern cod during Periods 1-3: (A) Period 1, (B) Period 2 and (C) Period 3

reared cod had wild-caught parents, while the southern fish were offspring of first-generation reared cod, which could be a potential source of bias if growth is under strong selection. However, it is not likely that selection for growth in the hatcheries could be strong enough to explain the results (see Law 2000). The observed differences are neither likely to be due to individual family effects, since a likely minimum of 7 to 8 and 12 to 13 females mothered the southern and northern offspring, respectively. Parental stocks adapted to different environments, and hence the existence of sub-populations is therefore likely to cause the results.

\section{Local retention of early life stages}

Marine species without parental care of offspring are generally thought to be well connected via long- distance dispersal of early stages via coastal currents. This is based on the assumption that egg and larval stages are transported passively by advective forces that allow extensive mixing. How can genetic isolation be maintained between northern and southern cod? Selection of spawning grounds in relation to stratified water masses, the following distribution of early life stages and adult migration strategies may explain this.

Coastal cod select spawning sites commonly situated in fjord backwaters and areas with a water residence time higher than that on the shelf banks (Hutchings et al. 1993, Brander 1994a, S. Sundby pers. comm.). The dynamics of the stratified water masses in coastal and fjord areas (Asplin et al. 1999), and the evolved buoyancy of both eggs and larvae allowing early life stages to ascend at a vertical speed $\left(1 \mathrm{~mm} \mathrm{~s}^{-1}\right)$ that much exceeds the typical speed of downwelling water (0.1 $\mathrm{mm} \mathrm{s}^{-1}$; Sundby 1983, 1991), may prevent egg stages from being transported away from the spawning site (Asplin et al. 1999). There is, however, a potential for downstream transport of early life stages to higher latitudes by the strong northward current, unless larvae counteract this through vertical migration (Asplin et al. 1999, Sponaugle et al. 2002). Switching between stratified water masses of inflowing and outflowing currents by active swimming is known for decapod crustaceans and fish larvae in coastal areas, and this strongly influences local retention and selfrecruitment in sub-populations (Sponaugle et al. 2002).

In addition to local retention of eggs and larvae, homing to the same spawning ground augments differentiation into sub-populations (Cowen et al. 2000). Mature Northeast Arctic cod have returned to the same spawning area since the ninth century (Brander 1994a). This phenomenon has also been reported recently for cod in Canadian waters (Robichaud \& Rose 2001). Genetically distinct sub-populations in bays, inlets and fjords have been identified in Canada (Ruzzante et al. 1996a, 1997, 2000) and Iceland (Jonsdottir et al. 2002), and among local spawning populations in the North Sea (Hutchinson et al. 2001). Tag-release-recapture experiments have shown that the juvenile and adult coastal cod in Norwegian waters tend to remain in their local areas (Salvanes \& Ulltang 1992, Jakobsen 1987, Nordeide \& Pettersen 1998, Svåsand et al. 2000). The different coastal and fjord sub-populations therefore have the potential to evolve life-history strategies adapted to local environmental conditions.

\section{Countergradient variation and life-history strategies}

Our study suggests that feeding strategies are likely to be associated with differences in growth potential between northern and southern coastal cod. No differ- 
ence in growth was found during the pre-experimental period, when northern and southern cod were housed for $450 \mathrm{~d}$ in identical environments in separate aquaria and fed until satiation. Northern and southern cod were therefore of equal size at the start of the experiment. During the common-garden experimental period fish competed for limited amounts of food. Due to their higher feeding success, northern cod achieved higher growth rates than southern cod.

Size and time constraints may select for active feeding

Environmental stress differs between high and low latitudes. Rapid growth is selected for when there are time constraints on reaching a minimum size. An example is size-dependent winter mortality in juvenile fish. Due to a shorter growth season at high latitudes, selection for rapid growth is strong to counteract the negative effect of the environment (Conover \& Present 1990, Conover 1992). Despite environmental stress at high latitudes, the potential growth rate evolves to a level beyond what local stress conditions dictate (Arendt 1997). This was found in the present study, in that reared northern cod (Fig. 1) had higher growth rate than southern cod when sharing aquaria under temperature conditions typical for the southern population.

A shorter growth season requires a more active strategy when prey is encountered, because it will be of great importance to catch every prey item, since the time frame for searching for and feeding on prey is limited. A more active feeding strategy is likely to explain the higher growth rate found in reared northern cod. Similarly, differences in food consumption between high- and low-latitude populations of Atlantic silverside (Menida menida) was explained by adaptation of high-latitude populations to a shorter growth season than southern populations (Present \& Conover 1992). Another abiotic environmental factor that constraints growth is low ambient temperature (Jobling 2002) due to temperature influences on enzymatic processes such as digestion (Knutsen \& Salvanes 1999), and thus assimilation and growth. Selection for individuals capable of fast growth under low temperature or other environmentally limiting circumstances might therefore also be favoured at high latitudes.

Density-dependent food competition may select for active feeding

An additional explanation for the development of higher intrinsic growth in northern cod is density- dependent food competition. Variation in prey type and density, as well as density of competitors and predators are all factors likely to influence feeding strategies in different environments (Reznick 1993). Northern fjords have a higher density of juvenile fish $\left(3.5 \mathrm{t} \mathrm{km}^{-2}\right)$ than southern fjords $\left(0.8 \mathrm{t} \mathrm{km}^{-2}\right)$, but there are fewer competing species in northern fjords and coastal areas (Svasånd et al. 2000). The lower CF in wild northern cod, which reflects an individual's recent feeding history and physiological allocation of resources (Jobling 2002), suggests food limitations in the north and indicates that the lower growth rate of northern cod is not solely due to delayed growth in response to the stress of low temperature. Food shortage caused by high intra-specific competition will result in lower net energy return per individual throughout the growth season and also a low CF in the wild. The higher intra-specific competition in the north thus selects for an active feeding strategy in juvenile cod to obtain prey whenever they are available.

\section{Feeding from the pelagic food web select for active feeding}

The diet in the different areas could also influence feeding behaviour. Cod in fjords of northern Norway feed mainly off the pelagic food web (shrimp, krill, herring, capelin) (Klemetsen 1982, dos Santos \& FalkPetersen 1989, Kanapathippilai et al. 1994). This implies that the nearly non-migrating northern coastal cod depend on high lipid prey migrating between fjords and the outer coast (Falk-Petersen 1981, Lawson et al. 1998) and on organisms drifting in advective water masses. In southern fjords cod rely more on prey associated with the bottom layers, the proportion of benthic prey consumed increasing with distance from the coast (Table 5 in Salvanes et al. 1995). Pelagic feeding implies high prey abundance at times, but also greater uncertainty regarding food availability (Salvanes et al. 1995, Marshall et al. 1999). In contrast, feeding on less-abundant local benthic prey allows for a lower but constant food supply for non-migratory southern coastal cod (Salvanes et al. 1995). To successfully catch prey from the pelagic food web, northern cod may therefore have evolved a more active feeding behaviour than southern cod.

\section{Time constraints on feeding favours storage}

Throughout the experiment, differences in the energy-allocation patterns of the 2 populations were

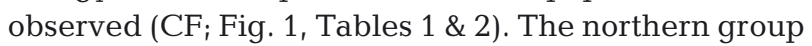
had higher growth in CF both in the wild and in the 
'common-garden' experiment, implying a relatively larger allocation to storage tissues. As has been shown for salmon (Bull et al. 1996), this indicates that the prolonged period of food shortage in the north selects for higher and earlier energy allocation to storage. The lower absolute CF (Fig. 1, Table 1) among the northern cod is likely due to low individual energy intake caused by the environmental constraints, since the relative changes in CF was higher in the northern population. Thus, relatively more of the energy was allocated to storage tissues also in the wild, consistent with our hypothesis and with what Bull et al. (1996) found for salmon.

\section{Gross food conversion efficiency}

We did not find any differences in GFCE between northern and southern cod. Although the existence of differences in GFCE is somewhat debated, since it does not come with any apparent costs (e.g. Conover \& Schultz 1995), it has been reported for several species including turbot (Scophthalmus maximus; Imsland et al. 2001) and cod from separate populations on the coast of Canada (Purchase \& Brown 2000). In the study of Purchase \& Brown (2000), strains were kept in separate tanks and fed to satiation, thus reducing the need for competition. In the present study the focus was on behavioural adaptations of the strains. Prey were therefore offered sequentially to target competition. Individuals of northern cod were rewarded by higher success in food consumption apparently caused by higher activity. Higher activity would, however, be linked with elevated energy expenditure that potentially could mask the effect of a higher GFCE. Further studies are therefore required to test for differences in GFCE among coastal cod sub-populations.

\section{Costs of high growth rate}

Energy and nutrients are budgeted among numerous of functions in an organism. Given a limited amount of resources, an increase in allocation for one function will decrease allocation for another. The functions may be categorized to growth including storage, development, maintenance, repair, defence, reproduction and movement (modified from Arendt 1997). Rapid growth in Atlantic salmon (Salmo salar) was correlated to a poor immune system (Saunders et al. 1992), and in Atlantic tomcod (Microgadus tomcod) increased liver damage was found after detoxification. Active feeding occurs at the expense of vigilance for predators (e.g. Lima 1998, Houston \& McNamara 1999, Skalski \& Gilliam 2002), since less time is spent to eval- uate predation risk. Such costs could have counteracted the evolution of a higher intrinsic growth rate in the southern population.

\section{Conclusions}

Fisheries represent additional 'human predation', potentially influencing the selection of life-history traits (e.g. Law 2000, Conover \& Munch 2002). Populations allowed to recover from over-fishing will therefore experience altered selection pressure. Subpopulations having different life histories may respond differently to both fisheries and altered selection pressures. Even though one cannot draw conclusions on how the observed behavioural differences found in this experiment will affect vulnerability to fishing, such behavioural traits could be important. This study has shown that there may be localised, behaviourally different populations of cod along the Norwegian coast. Frank \& Brickman (2000) suggested that the slow recovery of exploited species such as the Atlantic cod could be because behavioural differences between sub-populations are associated with differences in vulnerability to fisheries, and that this is masked and not accounted for when data are aggregated for fisheriesmanagement purposes. Future studies may therefore show that differences such as those found in this study also need to be considered for improving fisheries management.

Acknowledgements. We thank F. Huntingford, J. T. Nordeide, J. Giske, Ø. Fiksen and 5 anonymous referees, whose comments to an earlier version improved this paper significantly. We also thank A. Folkvord, P. Jakobsen, S. Sundby and J. Titelman for their valuable comments and thoughts on the work, and Ø. Karlsen and M. Hordnes for their assistance during the experiment and K. Skaaja for the fish. This project was funded by the Research Council of Norway (project no. 130192/140, environmental influence on fish stocks).

\section{LITERATURE CITED}

Anon (2003) Havets ressurser 2003. Fisken og Havet, Særnummer 1, Institute of Marine Research, Bergen

Arendt JD (1997) Adaptive intrinsic growth rates: an integration across taxa. Q Rev Biol 72:149-177

Asplin L, Salvanes AGV, Kristoffersen JB (1999) Nonlocal wind-driven fjord-coast advection and its potential effect on plankton and fish recruitment. Fish Oceanogr 8: 255-263

Bentzen P, Taggart CT, Ruzzante DE, Cook D (1996) Microsatellite polymorphism and the population structure of cod (Gadus morhua) in the North West Atlantic. Can J Fish Aquat Sci 53:2706-2721

Bergstad OA, Jørgensen T, Dragesund O (1987) Life history and ecology of the Gadoid resources of the Barents Sea. Fish Res 5:119-161 
Blindheim J (2004) Oceanography and climate. In: Skjodal HR (ed) The Norwegian Sea ecosystem. Chap 3. Tapir, Trondheim

Brander K (1994a) Spawning and life history information for North Atlantic cod stocks. ICES Coop Res Rep No 205

Brander K (1994b) Patterns of distribution, spawning, and growth in North Atlantic cod: the utility of inter-regional comparisons. ICES Mar Sci Symp 198:406-413

Bull CD, Metcalfe NB, Mangel M (1996) Seasonal matching of foraging to anticipated energy requirements in anorexic juvenile salmon. Proc Roy Soc Lond Ser B Biol Sci 263: $13-18$

Calow P (1982) Homeostasis and fitness. Am Nat 120:416-419

Carrol SP, Corneli PS (1999) The evolution of behavioural norms of reaction as a problem in ecological genetics: theory, methods and data. In: Foster S, Endler JA (eds) Geographic variation in behaviour. Perspectives on evolutionary mechanisms. Oxford University Press, Oxford, p 52-61

Conover DO (1992) Seasonality and the scheduling of life history at different latitudes. J Fish Biol 41(Suppl):161-178

Conover DO (2000) Darwinian fishery science. Mar Ecol Prog Ser 208:299-313

Conover DO, Munch SB (2002) Sustaining fisheries yield over evolutionary time scales. Science 297:94-96

Conover DO, Present TMC (1990) Countergradient variation in growth-rate - compensation for length of the growingseason among Atlantic silversides from different latitudes. Oecologia 83:316-324

Conover DO, Schultz ET (1995) Phenotypic similarity and the evolutionary significance of countergradient variation. Trends Ecol Evol 10:248-252

Cowen RK, Lwiza KMM, Sponaugle S, Paris CB, Olson DB (2000) Connectivity of marine populations: Open or closed? Science 287:857-859

dos Santos J, Falk-Petersen S (1989) Feeding ecology of cod (Gadus morhua L.) in Balsfjord and Ullsfjord, northern Norway. 1982-1981. J Cons Int Explor Mer 45:190-199

Elliott JM (1989) Growth and size variation in contrasting populations of trout Salmo trutta: an experimental study on the role of natural selection. J Anim Ecol 58:45-58

Falk-Petersen S (1981) Ecological investigations on the zooplankton community of Balsfjorden, Northern Norway: seasonal changes in body weight and the main biochemical composition of Thysanoessa inermis (Krøyer), T. rashii (M. Sars) and Meanyctiphanes norvegica (M. Sars) in relation to environmental factors. J Exp Mar Biol Ecol 49:103-120

Fevolden SE, Pogson GH (1997) Genetic divergence at the synaptophysin (Syp 1) locus among Norwegian Coastal and North-East Arctic populations of Atlantic cod. J Fish Biol 51:895-908

Fordham SE, Trippel EA (1999) Feeding behaviour of cod (Gadus morhua) in relation to spawning. J Appl Ichthyol 15:1-9

Foster S, Endler JA (1999) Geographic variation in behaviour. Perspectives on evolutionary mechanisms. Oxford University Press, Oxford

Frank KT, Brickman D (2000) Allee effects and compensatory population dynamics within a stock complex. Can J Fish Aquat Sci 57:513-517

Gjerde B (1986) Growth and reproduction in fish and shellfish. Aquaculture 57:37-55

Houston AI, McNamara JM (1999) Models of adaptive behaviour: an approach based on state. Cambridge University Press, New York

Hutchings JA (2000) Collapse and recovery of marine fishes. Nature 406:882-885

Hutchings JA, Morris DW (1985) The influence of phylogeny, size and behaviour on patterns of covariation in salmonids' life histories. Oikos 45:118-124

Hutchings JA, Myers RA, Lilly GR (1993) Geographic variation in the spawning of Atlantic cod, Gadus morhua, in the Northwest Atlantic. Can J Fish Aquat Sci 50:2457-2467

Hutchinson WF, Carvalho GR, Rogers SI (2001) Marked genetic structuring in localised spawning populations of cod Gadus morhua in the North Sea and adjoining waters as revealed by microsatellites. Mar Ecol Prog Ser 223: 251-260

Imsland AK, Foss A, Stefansson SO (2001)Variation in food intake, food conversion efficiency and growth from different geographic strains. J Fish Biol 59:449-454

Jakobsen T (1987) Coastal cod in northern Norway. Fish Res 5:223-234

Jobling M (2002) Environmental factors and rates of development and growth. In: Hart PJB, Reynolds JD (eds) Handbook of fish and fisheries, Vol I. Blackwell, London, p 96-122

Jonsdottir ODB, Imsland AK, Danielsdottir AK, Marteinsdottir G (2002) Genetic heterogeneity and growth properties of different genotypes of Atlantic cod (Gadus morhua) at two spawning sites off south Iceland. Fish Res 55:37-47

Kanaphathippilai P, Berg E, dos Santos J, Gulliksen B, Pedersen T (1994) The food consumption of cod, Gadus morhua L., in a high-latitude enhancement area. Aquacult Fish Manage 25(Suppl 1):65-76

Klemetsen A (1982) Food and feeding habits of cod from the Balsfjord, northern Norway during a one year period. J Cons Int Explor Mer 40:101-111

Knutsen I, Salvanes AGV (1999) Temperature-dependent digestion handling time in juvenile cod and possible consequences for prey choice. Mar Ecol Prog Ser 181:61-79

Law R (2000) Fishing, selection and phenotypic evolution. ICES J Mar Sci 57:659-668

Lawson JW, Magalhães AM, Miller EH (1998) Important prey species of marine vertebrate predators in the Northwest Atlantic: proximate composition and energy density. Mar Ecol Prog Ser 164:13-20

Levins R (1969) Thermal acclimation and heath resistance in Drosophila species. Am Nat 103:483-499

Lima SL (1998) Stress and decision making under the risk of predation: recent developments from behavioral, reproductive, and ecological perspectives. Adv Stud Behav 27: 215-290

Marshall C, Yaragina YA, Lambert Y, Kjesbu OS (1999) Total lipid energy as a proxy for total egg production by fish stocks. Nature 402:288-290

Mork J, Giaever M (1999) Genetic structure of cod along the coast of Norway. Results from isozyme studies. Sarsia 84: 157-168

Mork J, Ryman N, Stahl G, Utter F, Sundnes G (1985) Genetic variation in Atlantic cod (Gadus morhua) throughout its range. Can J Fish Aquat Sci 42:1580-1587

Nordeide JT, Pettersen IH (1998) Haemoglobin frequencies and vertebral numbers of cod (Gadus morhua L.) off northern Norway-test of a population structure hypothesis. ICES J Mar Sci 55:134-140

Partridge L, Barrie B, Fowler K, French V (1994) Evolution and development of body size and cell size in Drosophila melanogaster in response to temperature. Evolution 48: 1269-1276

Pinoheiro JC, Bates DM (2000) Mixed-effects models in S and S-PLUS. Springer-Verlag, London

Present TMC, Conover DO (1992) Physiological basis of latitudinal growth differences in Menida menida-variation in consumption or efficiency. Funct Ecol 6:23-31 
Purchase CF, Brown J (2000) Interpopulation differences in growth rates and food conversion efficiencies of young Grand Banks and Gulf of Maine cod (Gadus morhua). Can J Fish Aquat Sci 57:2223-2229

Reznick DN (1993) Norms of reaction in fishes. In: Stokes TK, McGlade JM, Law R (eds) The exploitation of evolving resources. Lecture Notes in Biomathematics, SpringerVerlag, Berlin

Robichaud D, Rose GA (2001) Multiyear homing of Atlantic cod to a spawning ground. Can J Fish Aquat Sci 58: $2325-2329$

Ruzzante DE, Taggart CT, Cook D, Goddard SV (1996a) Genetic differentiation between inshore and offshore Atlantic cod (Gadus morhua L.) off Newfoundland: microsatellite DNA variation and antifreeze level. Can J Fish Aquat Sci 53:634-645

Ruzzante DE, Taggart CT, Cook D, Goddard SV (1997) Genetic differentiation between inshore and offshore Atlantic cod (Gadus morhua L.) off Newfoundland: a test and evidence of temporal stability. Can J Fish Aquat Sci 54:2700-2708

Ruzzante DE, Taggart CT, Cook D (1998) A nuclear DNA basis for shelf- and bank-scale population structure in northwest Atlantic cod (Gadus morhua): Labrador to Georges Bank. Mol Ecol 7:1663-1680

Ruzzante DE, Wroblewski JS, Taggart CT, Smedbol RK, Cook D, Goddard SV (2000) Bay-scale population in coastal Atlantic cod in Labrador and Newfoundland, Canada. J Fish Biol 56:431-447

Salvanes AGV, Ulltang $\varnothing$ (1992) Population parameters, migration and exploitation of the cod (Gadus morhua L.) in Masfjorden, western Norway. Fish Res 15:253-289

Salvanes AGV, Aksnes DL, Fosså JH, Giske J (1995) Simu-

Editorial responsibility: Roger Hughes (Contributing Editor), Bangor, United Kingdom lated carrying capacities of fish in Norwegian fjords. Fish Oceanogr 4:17-32

Saunders RL, Farrell AP, Knox DE (1992) Progression of coronary arterial lesions in Atlantic salmon (Salmo salar) as a function of growth rate. Can J Fish Aquat Sci 49:878-884

Skalski GT, Gilliam JF (2002) Feeding under predation hazard: testing models of adaptive behaviour with stream fish. Am Nat 160:158-172

Sponaugle S, Cowen RK, Shanks A, Morgan SG and 7 others (2002) Predicting self-recruitment in marine populations: Biophysical correlates and mechanisms. Bull Mar Sci Sci 70(Suppl S):341-375

Sundby S (1983) A one-dimensional model for the vertical distribution of pelagic fish eggs in the mixed layers. DeepSea Res 30(6A):645-661

Sundby S (1991) factors affecting the vertical distribution of eggs. ICES Mar Sci Symp 192:33-38

Sutherland WJ (1996) From individual behaviour to population ecology. Oxford series in Ecology and Evolution, Oxford University Press, Oxford

Suthers IM, Sundby SS (1996) Role of the midnight sun: comparative growth of pelagic juvenile cod (Gadus morhua) from the Arcto-Norwegian and a Nova Scotian stock. ICES J Mar Sci 53:827-836

Svåsand T, Jørstad KE, Otterå H, Kjesbu OS (1996) Differences in growth performance between Arcto-Norwegian and Norwegian coastal cod reared under identical conditions. J Fish Biol 49:108-119

Svåsand $\mathrm{T}$, Kristiansen TS, Pedersen $\mathrm{T}$, Salvanes AGV, Engelsen R, Nævdal G, Nødtvedt M (2000) The biological and economical basis of cod stock enhancement. Fish Fish $1: 173-205$

Submitted: June 3, 2003; Accepted: November 14, 2003 Proofs received from author(s): February 2, 2003 